\title{
Analysis of Influencing Factors of Life Insurance in Beijing Area
}

\author{
Qian Zhang \\ School of Economics and Management \\ North China University of Technology \\ Beijing, China \\ E-mail: 528690807@qq.com
}

\author{
Xuefeng Zhang * \\ School of Economics and Management \\ North China University of Technology \\ Beijing, China \\ E-mail: zxf511@163.com
}

\begin{abstract}
In recent years, people have been increasingly concerned about life security in the future. Based on the data of life insurance in Beijing from 1997 to 2015, this paper analyzes the long-term impact and short-term impact of various factors, using vector error correction model. It indicates that regional final consumption expenditure and GDP have both long-term and short-term effects on the demand for life insurance. In conclusion, in long run national consumption needs to be further stimulated; in short run, proper measures should be used for publicity. Market strategy should be constantly innovated, and computer applications also need to upgrade.
\end{abstract}

Keywords—life insurance; Vector error correction model; Long term influence; Short term impact

\section{INTRODUCTION}

From 1980 to 2015, Premium income in China saw an exponential growth. In 2015, in the light of the scale of the premium, all premium income of Beijing, Tianjin and Hebei region accounted for only about $13 \%$ of the country. Although the economic development in these areas is swift and violent, there is still great room for development in the insurance industry. With the intensification of competition ${ }^{[1]}$, the system of the insurance industry is more perfect and more efficient . As a main part of insurance, life insurance also has good prospects for development. Taking Beijing area as an example, this paper discovers the factors that affect the demand for life insurance considering both long term and short term. Sara Emamgholipour, Mohammad Arab, Zahra Mohajerzadeh $^{[2]}$ analyzed the determinants of life insurance demand during 2004-2012. Results show that the price elasticity of life insurance demand is -0.77 , the elasticity of life insurance subject to HDI is 1.68 , the elasticity of life insurance subject to GDP is 0.92 , and the elasticity of life insurance subject to interest rate is -0.33 . Abdul Latif Alhassan $^{[3]}$ used the auto-regressive distributed lags bounds approach to cointegration, based on annual time-series data from 1990 to 2010,The results of the bound test shows a longrun relationship between insurance market activities and economic growth for Kenya, Mauritius, Morocco, Nigeria and South Africa. Amlan Ghosh ${ }^{[4]}$ used the VAR-VECM model to find out the long run and short run relationship (if any) between life insurance growth and economic growth along with Granger causality test to suggest any causal

Supported by the North China University of Technology outstanding young teacher training program, funded Beijing Social Science Foundation (Grant No.16LJC008) and Foundation for The Excellent Youth Scholars of Beijing(Grant No.2016000020124G021) relationship. This study finds that there is long term relationship between life insurance industry and economic development in India.

\section{OVERVIEW OF LIFE INSURANCE}

\section{A. The concept and characteristics of life insurance}

Life insurance regards life and body as the subjects of insurance, insurance premium will be given to the insured when the insured suffers accidents, disability, severe diseases and aging. The characteristics of life insurance are as follows(1) an insurance contract with the nature of fixed payment; (2) long-term insurance contracts;(3) insurance of savings; (4) without the existence of over-insurance, double insurance and subrogation-right problems.

\section{B. The chart of life insurance}

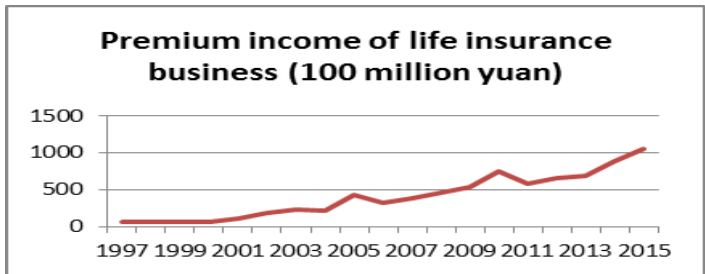

Fig. 1. The timing chart of premium income in life insurance

Fig. 1 depicts the timing chart of life insurance premiums (million Yuan) in China during from 1997 to 2015.On the whole; premium income shows a trend of yearly increase. It shows that the popularity and recognition of life insurance among people are increasing year by year, and it also shows that the effective demand for insurance is increasing year by year. The market has not yet reached saturation, and there is still a great room for development.

\section{Analysis of the impact of gross domestic product on the premium income of life insurance companies}

Changes in the life insurance demand caused by changes in the gross domestic product (GDP) ${ }^{[5]}$ can be expressed by the elasticity of the demand for life insurance. 
TABLE I. ELASTICITY TABLE OF PREMIUM INCOME OF LIFE INSURANCE COMPANY

\begin{tabular}{|c|c|c|c|c|c|}
\hline years & $\begin{array}{c}\text { Gross } \\
\text { Domestic } \\
\text { Product } \\
\text { ( hundred } \\
\text { million } \\
\text { RMB ) }\end{array}$ & $\begin{array}{c}\text { Gross } \\
\text { Domestic } \\
\text { Product } \\
\text { Growth } \\
\text { Rate (\%) }\end{array}$ & $\begin{array}{c}\text { Life } \\
\text { insurance } \\
\text { company's } \\
\text { premium } \\
\text { income } \\
\text { ( hundred } \\
\text { million } \\
\text { RMB ) } \\
\end{array}$ & $\begin{array}{c}\text { Life } \\
\text { insurance } \\
\text { company's } \\
\text { premium } \\
\text { income } \\
\text { growth } \\
\text { rate (\%) }\end{array}$ & $\begin{array}{c}\text { The } \\
\text { elasticity of } \\
\text { premium } \\
\text { income to } \\
\text { gross } \\
\text { domestic } \\
\text { product } \\
\text { (GDP) }\end{array}$ \\
\hline 2001 & 110863.1 & & 1425 & & \\
\hline 2002 & 121717.4 & 0.097907 & 2275 & 0.596491 & 6.092412 \\
\hline 2003 & 137422 & 0.129025 & 2983 & 0.311209 & 2.412002 \\
\hline 2004 & 161840.2 & 0.177688 & 3198 & 0.072075 & 0.405628 \\
\hline 2005 & 187318.9 & 0.157431 & 3645 & 0.139775 & 0.887847 \\
\hline 2006 & 219438.5 & 0.17147 & 4059 & 0.11358 & 0.662391 \\
\hline 2007 & 270232.3 & 0.231472 & 4947 & 0.218773 & 0.94514 \\
\hline 2008 & 319515.5 & 0.182373 & 7338 & 0.483323 & 2.650184 \\
\hline 2009 & 349081.4 & 0.092534 & 8144 & 0.109839 & 1.18702 \\
\hline 2010 & 413030.3 & 0.183192 & 10501 & 0.289416 & 1.579849 \\
\hline 2011 & 489300.6 & 0.18466 & 9560 & -0.08961 & -0.48527 \\
\hline 2012 & 540367.4 & 0.104367 & 9958 & 0.041632 & 0.398898 \\
\hline 2013 & 595244.4 & 0.101555 & 10741 & 0.07863 & 0.774263 \\
\hline 2014 & 643974 & 0.081865 & 12690 & 0.181454 & 2.216509 \\
\hline 2015 & 685505.8 & 0.064493 & 15859 & 0.249724 & 3.872115 \\
\hline
\end{tabular}

According to the relevant data of gross domestic product and life insurance income, the elasticity of life insurance premium income to GDP in the 2001-2015 years can be calculated. The results show that the elasticity of life insurance premiums to GDP is uneven, Generally speaking, life premium income will increase with the growth of GDP. It is noticed that the elasticity has a negative value, and if the effect of other factors is excluded, the elasticity should be positive.

\section{ANALYSIS OF LIFE INSURANCE DEMAND BASED ON VECTOR ERROR CORRECTION MODEL ${ }^{[6]}$}

In order to study the quantitative relationship between the demand for life insurance and its influencing factors in China, this paper takes the Beijing market as an example, and establishes the appropriate model.

\section{A. Theoretical framework and research methods ${ }^{[7]}$}

\section{1) Stationarity test of time series variables}

For random vectors $\boldsymbol{x}_{\boldsymbol{t}}=\left(\begin{array}{llll}x_{1 t} & x_{2 t} & \cdots & x_{N t}\end{array}\right)^{\prime}$, If (1) $x_{t} \sim I(d)$ ( each component of $x_{t}$ is d-order nonstationary)(2) there exists a $\mathrm{N} \times 1$ order column vector $\boldsymbol{\beta},(\boldsymbol{\beta} \neq 0)$, which enables $\boldsymbol{\beta}^{\prime} \boldsymbol{x}_{\boldsymbol{t}} \sim I(d-b)$, these variables $\left(X_{1 t}, X_{2 t}, \cdots, X_{N t}\right)$ have co-integration relations with the order of (d, b). That is, $\boldsymbol{x}_{\boldsymbol{t}} \sim \mathrm{CI}(d, b), \boldsymbol{\beta}$ Called co- integration vector. The elements of $\boldsymbol{\beta}$ are called cointegration parameters. Co-ordination means the existence of long-term equilibrium relations.

If two (or more) time-series variables exist equilibrium relationship in the long run, even the time series unstable, they will show the same trend because of their stable deviation, as time goes on. If there is a co-integration relationship between two non-stationary variables, then the linear deviation between them, the non-balanced error, is stationary.

\section{2) Vector error correction model}

Granger theorem shows that, for any set of variables $I(1)$, the error correction model is equivalent to co-integration. This means that if there is co-integration between variables, there must be a corresponding vector error correction model . the error correction model implies the concrete representation of co-integration relationship.

\section{B. An Analysis of the Factors Affecting the Demand for life Insurance in China}

Using relevant data, the logarithmic sequence diagram of Premium income, regional GDP and regional final consumption expenditure from 1997 to 2015 is shown in Fig. 2:

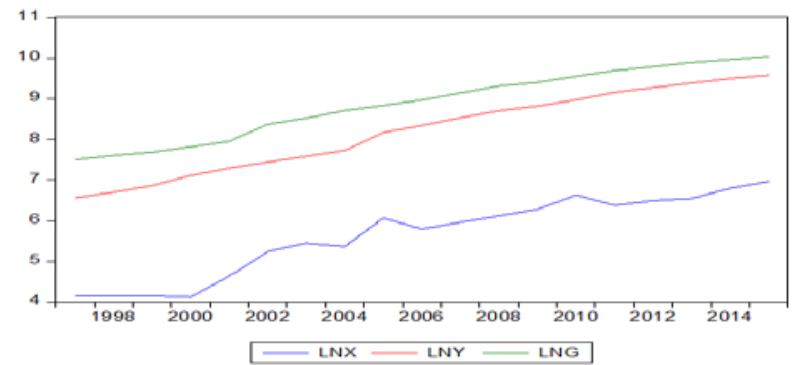

Fig. 2. In 1997-2015 years, Logarithmic time series diagram of life insurance premiums, final consumption expenditures and GDP

In Fig. 2, LNX represents the logarithm of the premium income of life insurance business, LNY represents the logarithm of the final regional consumption expenditure, and LNG represents the logarithm of regional GDP, From the graph, we can see that they have obvious trends in the same direction.

C. The relationship between Premium income of life insurance, regional gross domestic product and regional final consumption expenditure ${ }^{[8]}$

1) Unit root test

Unit root test refers to whether there is a unit root in the test sequence, Any existence of unit roots implies that the time sequence is non-stationary. Therefore, if we want to test the co-integration relationship of life insurance premium income, regional gross domestic product and regional final consumption expenditure, it is necessary to test the existence of unit roots for each sequence firstly, that is, testing their stationarity. Thus, the unit root test is performed for logarithmic time series data of the variables. This paper adopts 
the ADF method, the original hypothesis is the existence of unit root.

The ADF unit root test is used in the logarithmic time series and the first order difference sequence in Eviews. The $\mathrm{ADF}$ unit root test of logarithmic time series shows that the values of the $\mathrm{P}$ statistic are $0.7176,0.5235$ and 0.5936 , respectively, and they are all greater than 0.05 . That is, the logarithmic time series of these variables cannot reject the null hypothesis at the significance level of $5 \%$. The logarithmic time series of these three variables are unstable.

Test results of first order differential ADF unit root with intercept are obtained, and the values of the $\mathrm{P}$ statistics are $0.0013,0.0197$ and 0.0260 respectively, and they are all less than 0.05 .That is, under the significance level of $5 \%$, the original hypothesis can be rejected based on the first difference of each variable. That is, the first order differential stability of the three variables is obtained, $I(1)$. Then, the Johansen method can be used to test the co-integration relationship.

\section{2) Johansen cointegration test ${ }^{[9]}$}

Before the Johansen co-integration test, the VAR model should be established first. The VAR model with different lag periods is established for the logarithmic time series data of Premium income of life insurance, regional GDP and regional final consumption expenditure. Then, the Johansen cointegration test is performed on the basis of the VAR model, and the test results are shown in table II:

\section{TABLE II. RESULTS OF JOHANSEN COINTEGRATION TEST}

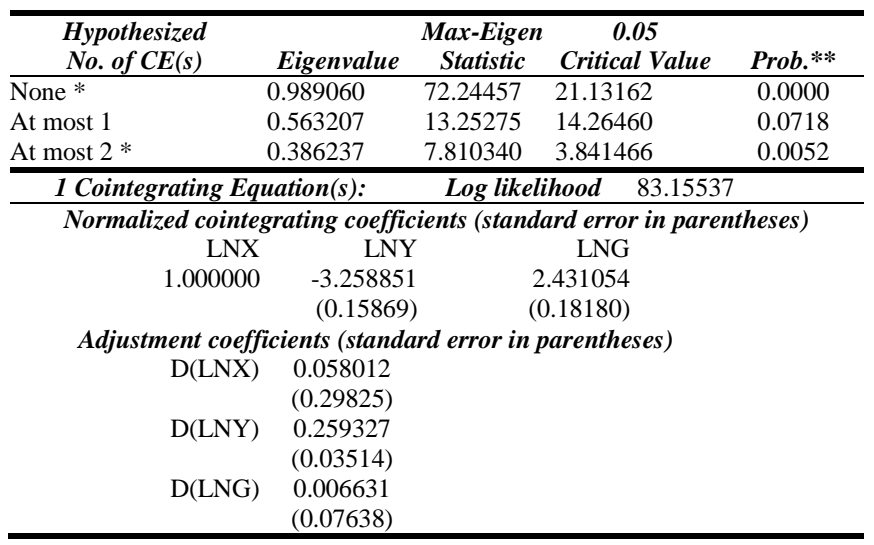

The maximum eigenvalue statistic shows that there exists co-integration relationship. The Standardized co-integration coefficients of LNX, LNY and LNG are 1, -3.26 and 2.43, respectively. Therefore, the co-integration relationship can be expressed as a mathematical expression, and it can be equal to VECM.

$$
\text { vecm=LNX-3.26LNY+2.43LNG }
$$

The equation reflects some kind of long-term equilibrium relationship between sequences.
Inverse Roots of AR Characteristic Polynomial

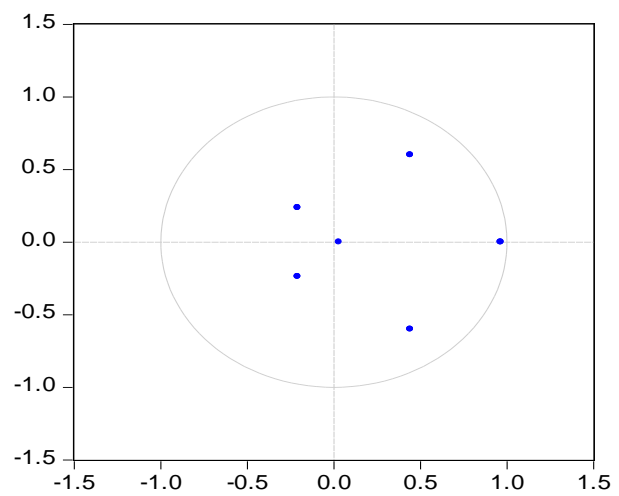

Fig. 3. The diagram of the AR root

The representation of Fig. 3 is very intuitive, and the reciprocal modules of all unit roots fall within the unit circle, so the VAR (2) model is stable, which proves that the cointegration relation is correct, and the value of VECM fluctuates near 0 .In the long run, VECM will be equal to 0 , so the relationship between LNX, LNY and LNG is LNX=3.26LNY-2.43LNG. Because the three variables (life insurance premiums, regional GDP and regional final consumption expenditure) have taken their natural logarithm, the following conclusions can be drawn.

- In the long run, the elasticity coefficient of the final consumption expenditure and the life insurance demand in Beijing is 3.26. That is, with an increase of $1 \%$ in regional final consumption expenditure, the demand for life insurance will rise by $3.26 \%$. This is in line with the general economic phenomenon, the final consumption expenditure increases, and the proportion of life insurance expenditure to total expenditure also increases accordingly. From the result, stimulating consumption and increasing the publicity of life insurance is conducive to promoting the needs of life insurance.

- In the long run, the elasticity coefficient of regional GDP and life insurance demand is -2.43 . That is, GDP increases by $1 \%$, and the demand for life insurance will decrease by $2.43 \%$. This does not seem to agree with the common sense, and the explanation is as follows: in the long run, with the continuous growth of GDP, the social security system in Beijing is becoming more and more perfect, the index of happiness is getting higher and higher. As a result, the needs will be relatively reduced due to the sense of safety brought by life insurance.

\section{Estimation results of vector error correction model}

Finally, under the constraint of co-integration relationship, the vector error correction model for the demand function of life insurance is established, and the short-term fluctuation in long-term equilibrium is observed. The fitting results of the model are shown in table III below. The values of AIC and SC are -4.043538 and -3.161312 , respectively. The two values are relatively small, and the overall fitting effect of the model is better. 
TABLE III.

THE FITTING RESULT OF VECTOR ERROR CORRECTION MODEL FOR LIFE INSURANCE DEMAND IN BEIJING

\begin{tabular}{cccc}
\hline Error Correction: & $\boldsymbol{D}(\mathbf{L N X})$ & $\boldsymbol{D}(\mathbf{L N Y})$ & $\boldsymbol{D}(\mathbf{L N G})$ \\
\hline CointEq1 & -0.694195 & 0.096438 & 0.202304 \\
& $(0.53066)$ & $(0.16941)$ & $(0.15781)$ \\
D(LNX(-1)) & {$[-1.30818]$} & {$[0.56926]$} & {$[1.28195]$} \\
& 0.041466 & -0.161749 & 0.036561 \\
& $(0.36046)$ & $(0.11508)$ & $(0.10720)$ \\
D(LNY(-1)) & {$[0.11504]$} & {$[-1.40557]$} & {$[0.34106]$} \\
& 0.044234 & 0.124538 & -0.250797 \\
& $(1.09870)$ & $(0.35076)$ & $(0.32674)$ \\
D(LNG(-1)) & {$[0.04026]$} & {$[0.35506]$} & {$[-0.76757]$} \\
& 0.796517 & 0.259705 & -0.058198 \\
& $(0.94456)$ & $(0.30155)$ & $(0.28090)$ \\
& {$[0.84327]$} & {$[0.86124]$} & {$[-0.20718]$} \\
& 0.035698 & 0.135657 & 0.189530 \\
& $(0.25810)$ & $(0.08240)$ & $(0.07676)$ \\
& {$[0.13831]$} & {$[1.64638]$} & {$[2.46926]$} \\
\hline
\end{tabular}

$$
\begin{gathered}
\mathrm{d}(\mathrm{LNX})=-0.694 \times \mathrm{vecm}+0.041 \times \mathrm{d}(\mathrm{LNX}(-1))+0.044 \times \mathrm{d}(\mathrm{LN} \\
\mathrm{Y}(-1))+0.797 \times \mathrm{d}(\mathrm{LNG}(-1))+0.036
\end{gathered}
$$

Among them, vecm=LNX-3.26LNY+2.43LNG

From the fitting equation, the long term coefficient is -0.694 , and the original equation is corrected to a certain extent, shortterm shocks are also worthy of attention similarly. The following conclusions can be drawn from the equation (2) above:

- The growth rate of life insurance demand increased by $1 \%$ in the previous period, and it will affect the next period of life insurance needs and the growth rate of life insurance demand increases by $0.041 \%$ in the next period.

- The growth rate of the final consumption expenditure in the previous period increased by $1 \%$, It will have a positive impact on the next period of life insurance demand, The growth rate of the next phase of life insurance demand increases by $0.044 \%$. Since consumer preferences in the short term are basically stable, there will be no significant changes. But in the long run, consumer preferences are subject to subjective and objective factors and change largely. So it will affect the structure of the final consumption expenditure, and thus affect the demand for life insurance. Therefore, its long-term impact on the demand for life insurance is greater than the shortterm impact.

- The growth rate of GDP in Beijing increases by $1 \%$ in the previous period, and it will have a positive impact on the growth of demand for the next phase of life insurance. The next growth rate of demand for life insurance will increase by $0.797 \%$. In these three variables, Lagged Regional GDP has the greatest impact on the next life insurance demand.In addition, this result is different from the long-term analysis process mentioned previously. In the long run, the growth of GDP in Beijing will have a negative impact on the demand for life insurance. But the short-term impact of GDP on life insurance needs is positive, which is in line with the general Economic phenomenon.

\section{CONCLUSION}

(1)In 1997 -2015, the premium income of life insurance in China showed a trend of increasing year by year, and the premium income of life insurance increased with the growth of GDP.

(2)In the long run, with an increase of $1 \%$ in regional final consumption expenditure, the demand for life insurance will rise by $3.26 \%$. We need to stimulate national consumption and develop the economy further, With the continuous improvement of living standards, the demand for life insurance is increasing.

(3) The short-term shocks to all factors are relatively small. For individuals, consumption habits are different from each other and also relatively fixed in short term. For groups without willingness to buy insurance, proper methods can be used for publicity. Insurance marketing technology is constantly being innovated, and computer applications also need to upgrade, so that customers can easily search for relevant information.

\section{REFERENCE}

[1] J. David Cummins,María Rubio-Misas,Dev Vencappa.Competition, efficiency and soundness in European life insurance markets[J]. Journal of Financial Stability,2017(28):66-78.

[2] Sara Emamgholipour,Mohammad Arab,Zahra Mohajerzadeh. Life insurance demand: Middle East and North Africa[J]. International Journal of Social Economics,2017,44(4): 521-529.

[3] Abdul Latif Alhassan.Insurance market development and economic growth[J]. International Journal of Social Economics,2016,43(3):321339.

[4] Amlan Ghosh. Does life insurance activity promote economic development in India: an empirical analysis[J]. Journal of Asia Business Studies,2013,7(1):31-43.

[5] Simona Laura Dragos. Life and non-life insurance demand: the different effects of influence factors in emerging countries from Europe and Asia[J]. Economic Research-Ekonomska Istraživanja,2014,27(1):169180.

[6] Li Zinai, Pan Wenqing. Econometrics (Third Edition) [M]. Beijing:Higher Education Press,2010(In Chinese).

[7] Zhang Xiaotong. Applied quantitative economics [M]. Beijing:Machinery Industry Press,2009(In Chinese).

[8] Zhang Xiaotong. Eviews usage guidelines and cases [M]. Beijing:Machinery Industry Press,2007(In Chinese).

[9] Su Su, Teng Yang. Analysis and prediction of influencing factors of energy consumption in China based on Cointegration and error correction model [J]. Eco economy,2016,32(6):73-76(In Chinese). 